\title{
THE NATURE OF RIBA IN ISLAM
}

\author{
By: $M$. Umer Chaprat
}

\section{Abstrak}

Perdebatan masalab riba seperti tidak pernah selesai di diskusikan oleb banyak kalangan, baik akademis, organisasi keagamaan, babkan sampai pada forum-forum intenasional. Beberapa terminologi dibahas dengan baik dalam tulisan ini yang dimulai dengan pelarangan riba itu sendiri kemudian pembagian-pembagian riba, diantaranya riba al-Nasi'ab dan riba al-Fadl, serta implikasi dari dua bentuk riba tersebut. Pembabasan didukung dengan pendapatpendapat para ulama dan ekonom yang merujuk langsung dari gyat-ayat al-Qur'an, sampai pada perdebatan bukum. Demikian juga al-Qur'an sangat jelas membedakan antara riba dan perdagangan, namun pelarangan riba sangat jelas babkan diperkuat dengan badits-badits yang dengan eksplisit melarang riba. Dijelaskan pula tentang perbedaan antara riba dan bunga bank. Islam sangat menentang bunga bank karena Islam berbarap terjadinya sistem ekonomi yang mengeliminasi selurub bentuk ketidakadilan dengan memperkenalkan keadilan antara pengusaba dan pemilik modal, yaitu berbagi resiko dan berbagi basil.

مستخلص تعد العدالة الاجتماعية - الاقتصادية أحسد أهم الغايات المنشّودة لكل المجتمعات الإنسانية على الرغم

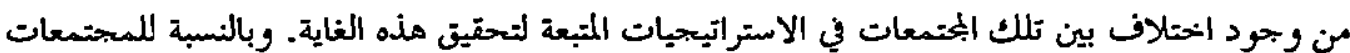

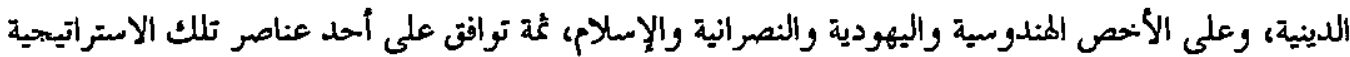

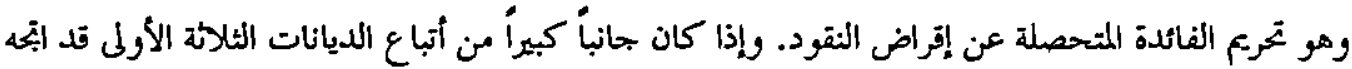

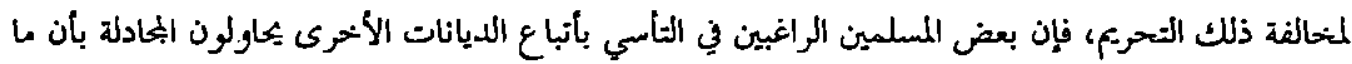

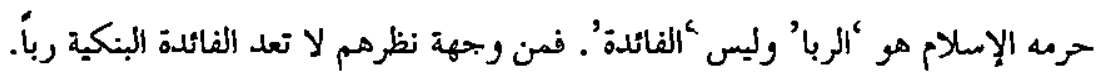
انطلاقا من تلك الإشكالية، وفي ضوء الثصوص الشرعية من قرآن وسنة وفقه، حاولت المقالة الإجابة ولهية

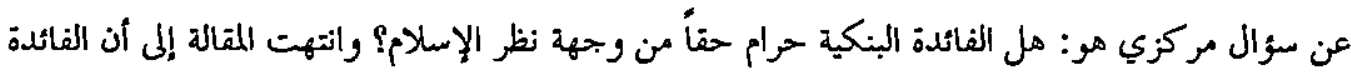

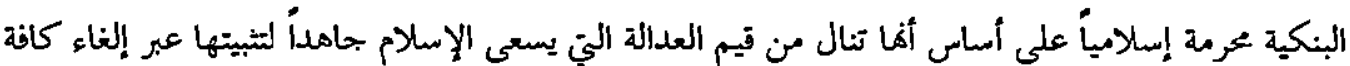

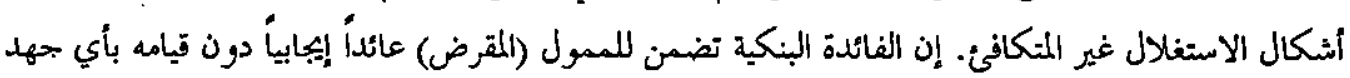

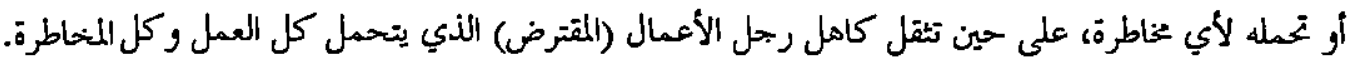

${ }^{1}$ M. Umer Chapra is a Serior Research Advisor at the Islamic Research and Training Institute (IRTI) of the Islamic Development Bank (IDB), Jeddah. 
كما كشفتت المقالة عن أن السبب وراء صعوبة إدراك حرمة الفائدة البنكية من الوملة الأوله يربع إلى

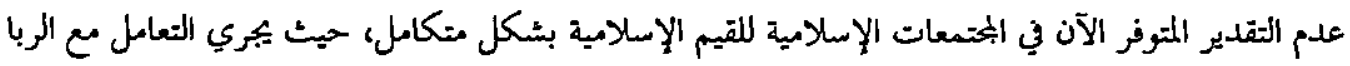

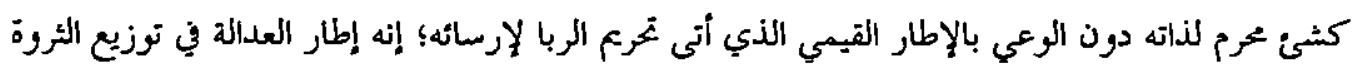

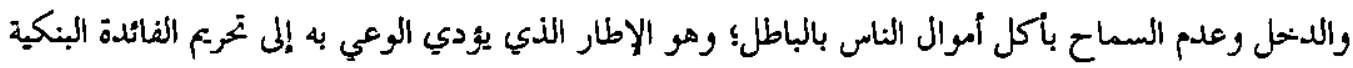
حتماً.

الكلمات المفتاحية جمعية كضة العلماء، السوق العائم، أصحاب المشروعات الصغيرة، نظام البنوك الشُرعية

\section{A. Introduction}

Socio-economic justice is one of the cherished goals of all societies. There is, however, a difference of opinion on the strategy that should be used to realize this goal. In spite of this difference, one element which is common in the strategy of four of the world's major religions (Hinduism, Judaism, Christianity, and Islam) is the prohibition of interest? ${ }^{2}$ Since the followers of the first three of these religions have in general moved away from this prohibition, there are some Muslims who wish to do the same by arguing that what Islam has prohibited is riba and not interest. In their opinion bank interest is not riba. ${ }^{3}$ This raises the question of whether interest is really prohibited in Islam. This paper tries to answer this question in the light of the Qur'an, badith and figh.

The consensus prevailing among Muslims throughout history has been, and continues to be, that riba among other things, includes interest. This consensus is clearly reflected in the unanimous verdict of a number of international conferences of fugaba (jurists) which have been held to discuss the question of riba, including the Mu'tamar al-Fiqb al-Lslami held in Paris in 1951 and in Cairo in 1965, and the

${ }^{2}$ For the Judaic and Christian views on intetest see Johris, et. al. (n.d.), and Noonan (1957); for the Hindu view, see Bokare, 1993, p. 168; and for the Islamic view, see Chapra, 1985, pp. 55-66, and Siddiqi, 2004, pp. 35-64

${ }^{3}$ Sir Sayyid Ahmad Khan (1817-98) was perhaps the first to argue that interest was not riba (See his Tafbim al-Qur'an (1880-95) Part 1, p.306, teferred to by Baljon, 1964, p. 45). M. Ma'uf al-Dawalibi also argued the same at the Mutamar al-Figh al-Islami in Paris in 1951. (See al-Sanhuri, 1953-4, Vol.3, Pp. 22749). For a somewhat revised version of this paper, see al-Dawalibi, 1988. Some of the others who followed suit are: Phulwarwi, 1959; Fazlur Rahman, 1964; Shah, 1967; Katouzian, 1979; M. Ali Khan, 1992, and Saeed, 1995 
OIC and Rabitah Fiqh Committee meetings held in 1985 and 1986 in Cairo and Makkah respectively. ${ }^{4}$

The Pakistan Council of Islamic Ideology clearly reflected this consensus when it concluded in its 1980 report on the elimination of interest from the Pakistan economy that: "The term riba encompasses interest in all its manifestations irrespective of whether it relates to loans for consumption purposes or for productive purposes, whether the loans are of a personal nature or of a commercial type, whether the borrower is a government, a private individual or a concern, and whether the rate of interest is low or high". 5

\section{B. The Prohibition of Riba}

The prohibition of riba appears in the Qur'an in four different revelations. ${ }^{6}$ The first of these (30:39), revealed in Makkah, emphasized that while interest deprived wealth of God's blessings, chatity raised it manifold. The second (4:161), revealed in the early Madinah period, severely condemned it, in line with its prohibition in the previous scriptures. It placed those who took riba in juxtaposition with those who wrongfully approptiated other people's property and threatened both with severe

4 al-Sanhuri, 1953-4, (1953-54), Razzaq al, Masadir al-Hagq fi al-Figh al-Islami (Beinut: Dar Thya' alTurath al- Ambi). Vol.3, pp.241-2 and al-Qaradawi, 1994, pp. $129-42$

sThe Federal Shari"ab Court in Pakistan also declared in its judgment that "riba includes both 'usury' and 'interest' as known in English terminology", 1992, p. 62. For a detailed discussion of the term riba, see the Federal Shari'ab Court Judgment on Interest (Riba), 1992, pp.31-109 and Chapra 1985, pp. 55-66 and 235-46

${ }^{6}$ First stage (Surah 30:39), That which you give as interest to increase the people's wealth increases not with God; but that which you give in charity, seeking the goodwill of God, multiplies manifold. (30:39). Second Stage (Surah 04:161), And for their taking interest even though it was forbidden for them, and their wrongful appropriation of other peoples' property, We have prepared for those among them who reject faith a grievous punishment. (4:161), Thind Siage (Surah 03:130-2), O believers, take not doubled and redoubled interest, and fear God so that you may prosper Fear the fire which has been prepared for those who reject faith, and obey God and the Prophet so that you may receive mercy. (3: 130-2). Fourth stage (Surah 02:275-281) 275. Those who benefit from interest shall be raised like those who have been driven to madness by the touch of the Devil; this is because they say: "Trade is like interest" while God has permitted trade and forbidden interest. Hence those who have received the admonition from their Lord and desist, may have what has already passed, their case being entrusted to God; but those who revert shall be the inhabitants of the fre and abide therein for ever. 276. God deprives interest of all blessing but blesses charity; He loves not the ungtateful sinner. 277.Those who believe, perform good deeds, establish prayer and pay the zakat, their reward is with their Lord; neither should they have any fear, nor shall they grieve 278 . O believers, fear God, and give up the interest that remains outstanding if you are believers. 
punishment from God. The third revelation (3:130-2), around the second or third year after Hijrah, enjoined Muslims to keep away from riba if they desired their owin welfare (in the comprehensive Islamic sense). The fourth'revelation. (2:275-81), near the completion of the Prophet's mission, severely censured those whốtake riba by declaring them to be at war with God and His Messenger, established a clear distinction between trade and riba, and required Muslims to annul all outstainding $r i b a$, , instructing them to take only the principal amount, and to forego 'even 'this in'case' of :the borrowers' hardship.

The Prophet, peace and blessings of God be on him, also condemined in the most unambiguous words not only those who take riba but also those who give riba and those who record the transaction or act as witnesses to it "Hè'éven equated the taking of-riba to committing adultery thirty-six times or being guilty of incest with one's own mother ${ }^{8}$

The meaning of riba

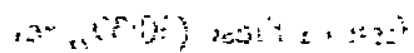

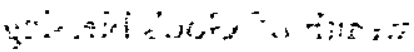

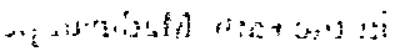

After knowing this severe verdict of the Qur'an and the Sunnab against riba; it is necessary to determine what the term riba really stands for Riba literally means increase, addition, expansion or growth. ${ }^{9}$ It is, however, not every increase or growth which has been prohibited by Islam. In the Shari ab, riba technically, refers to the

${ }^{7}$ From Jabir: The Prophet, may peace be on him, cursed the receiver and the payer of interest, the one who records the transaction and the two witnesses to the transaction and said: "They are all alike [in guilt]" (Muslim, Kitab al-Musagat, Bab lo'ana akil al-riba sa mu'kilaber, also in Tirmitihi and Musnad Ahmad).

${ }^{3}$ From Abdallah ibn Hanzalah: The Prophet, peace be on him, said: "A dirham of riba which a man receives knowingly is worse than committing adultery thirty-six times". (Mishkat al-Masabih, Kitab.al$B x y, B a b a l-r i b a$, on the authority of Ahmad and Daraqutni). Bayhaqi has also reported theiabove baditb in Sbrab al-Iman with the addition that "Hell befits him whose flesh has been nourished by the unlawful" (ibid) From Abu Huraytah: The Prophet, peace be on him, said: "On the night of Ascension I came upon people whose stomachs were like houses with snakes visible from the outside. I asked Gabriel who they were. He replied that they were people who had received interest":(Ibn Majah; Kitab al-Tijarab, Bab al-tagbliz ft al-riba, also in Musnad Ahmad). From Abu Hurayrah: The Prophet, peace be on him, said: "Riba has seventy segments, the least serious being equivalent to a man cormmitting adultery with his own mother" (Ibn Majah, ibid).

'See the word riba in Tbn Manzur's Lisan al-Arab, (vol. 14, 1968), pp. 3047; al-Zabidi's' Taj al'Arur, (vol. 10, 1306), pp. 142-3; and Raghib al-Isfahani's al-Mufradat,(1961), pp 186-7.-Ahe same'meaning is also unanimously indicated in all classical Qur'an commentaries. 
"premium" that must be paid by the borrower to the lender along with the principal amount as a condition for the loan or for an extension in its maturity. ${ }^{10}$

In this sense, riba has the same meaning and import as interest in accordance with the consensus of all the fuqaha without any exception. ${ }^{11}$ The term riba is, however, used in the Shari'ab in two senses. The first is riba al-nasi'ab and the second is riba al-fadl..$^{12}$

\section{Riba al-Nasi'ah}

The term nasiah comes from the root nasa'a which means to postpone, defer, or wait, and refers to the time that is allowed to the borrower to repay the loan in return for the 'addition' or the 'premium'. Hence riba al-nasi'ab is equivalent to the interest chatged on loans. It is in this sense that the term riba has been used in the Qur'an in verse 2:275, which states that "God has allowed trade and forbidden riba (interest)"

The prohibition of riba al-nasi' ab essentially implies that the fixing in advance of a positive rate of return on a loan as a reward for waiting is not permitted by the Shariab. It makes no difference whether the rate of return is small or big, or a fixed or

${ }^{10} \mathrm{Ibn}$ Manzur specifies that "what is prohibited is the extra amount, benefit or advantage received on any loan" (1968, p. 304). See also the commentary on verse 2:275 in Tofsir al-Kabir of Fakhruddin alRasi (Appendix 1.3.2), Abkan al-Qur'an of Abu Bakr al-Jassas and Abkam al-Qur'an of Ibn al-'Arabi, See also items 4, 5, 6, 7 and 8 of Appendix 3.

11 'Abd al-Rahman Jaziri, al-, Al-Fiqh ala ol-Madhabib al-Arba'ah, 5th ed. (Cairo: Al-Maktabah alTijariyyah al-Kubra, n.d), p. 245. (Abd al-Rabman al-Jatiri's Al-Figh Ala al-Madhabib al-Arba'ah, is a compendium on the juristic opinions of the four predominant schools of Muslim jurisprudence. It is held in high esteern and considered to be an authority on the subject. Given below are some relevant excerpts from this book on the subject of $r i b a$. "Definition and classification: "Riba is one of those unsound (fasid) transactions which have been severely prohibited (nabjan mughallazan). It literally means increase.. "However, in fiqh terminology, niba means an increase in one of two homogenous equivalents being exchanged without this increase being accompanied by a retum. It is classified into two categories.* First, riba al-nasiab where the specified increase is in return for postonement of, or waiting for, the payment; for example, buying an indab (a specific measure) of wheat in winter against an irdab and a half - of wheat to be paid in summer. As the half irdab which has been added to the price was not - accompanied by an equivalent value in the commodity sold and was merely in retum for the waiting, it is called riba al-Nasi'ab. The second category is riba olfadl, which means that the increase mentioned is irrespective of the postponement and is not offset by something in return. This happens when an irdab of wheat is exchanged hand to hand for an irdab.and a kilab (another measure) of the same quality of wheat, the buyer and the seller both taking reciprocal possession; or when ten carats of gold produce are exchanged for twelve carats of similar gold produce).

${ }^{12}$ Riba al-nari'ab is also called riba al-dyyu (riba on loans), riba al-mwbasbir (direct riba), or riba al-jali (obvious riba), while riba al-fadlis also called riba al-buy (iba in trade), riba gbagr al-mubasbir (indirect riba), or riba al-kboft (hidden riba). 
variable per cent of the principal, or an absolute amount to be paid in advance or on maturity, or a gift or service to be received as a condition for the loan. The point in question is the predetermined positiveness of the return. It is important to note that, according to the Shari'ah, the waiting involved in the repayment of a loan does not by itself justify a positive-reward.

There is hardly any room even for arguing that the prohibition applies only to consumption loans and not to business loans. This is because the borrowing during the Prophets' times was not for consumption purposes but rather mainly for financing ${ }^{\underline{\underline{z}}}$ long distance trade. Accordingly, the late Shaykh Abu Zahrah, one of the most prominent and respected Islamic scholars of this century, has rightly pointed out that:

There is absolutely no evidence to support that the riba of al-Jabiliyjab [pre-Islamic days] was on consumption and not on development loans. In fact the loans for which a research scholar finds support in history are production loans. The circumstances: of the Arabs, the position of Makkah and the trade of Quraysh, all lend support to the assertion that the loans were for production and not consumption purposes. ${ }^{13}$

Even Professor Abraham Udovitch, Ex-Chairman of the Department of Near Eastern Studies at the Princeton University, has clarified that "Any assertion that medieval credit was for consumption only-and not for production, is just untenable with reference to the medieval Near East".'4 Hence, the Quranic verse about remitting the principal in the event of the borrower's hardship does not refer to consumption loans. It refers essentially to interest-based business loans where the borrower had encountered losses and was unable to repay even the principal, leave alone the interest.

The whole argument that interest causes hardship only for the one who borrows for consumption needs is misfounded:- It is the obligation of the Muslim society to meet the dire consumption needs of the poor. Borrowing for conspicuous consumption has been_discoursed by Islam and most of the borrowing in the classical Muslim society was for business purposes.

It is only in this context that one-may be able to understand the argument of the Jabiliyyah that trade is like interest-and the distinction that the Qur'an draws between trade and interest. While in trade an entrepreneur has the prospect of making a profit, he also faces the risk of incurring a loss. In contrast with this, interest is

${ }^{13}$ M. Abu Zahrah, Bubuth fi al-Riba (Kuwait: Dar al-Buhuth al-Islamiyyah,1970), p.53-54

${ }^{14}$ Abraham Udovitch, Partnership and Profit in Medieval Islam (Princeton, NJ: Princeton University Press, 1970), p.86 
predetermined to be positive irrespective of the ultimate outcome of business, which may be positive or negative depending to a great extent on factors beyond the control of the entrepreneur. Imam Razi (d. 313AH/925AC) himself posed the question of what was wrong in charging interest when the borrower was going to employ the funds so borrowed in his business and' thereby earn a profit. His well-considered reply to the question was: "While the earning of profit is uncertain, the payment of interest is predetermined and certain. The profit may or may not be realized. Hence there can be no doubt that the payment of something definite in return for something uncertain inflicts a harm. ${ }^{15}$

Accordingly, riba is essentially in conflict with the clear and unequivocal Islamic emphasis on socio-economic justice. Financiers who do not wish to take the risk are entitled to only the principal and no more. Those who insist on charging riba in spite of its prohibition are declared by the Qur'an to be at war with God and His Prophet, peace be and blessings of God on him.

On the occasion of his Farewell Pilgtimage, the Ptophet, while declaring the abolition of interest, announced the remission of interest accumulated in favour of his uncle Abbas ibn Abd al-Muttalib. ${ }^{16}$ This was interest on business loans extended to the Banu Thaqif tribe. This tribe had not taken the loan from Abbas and others . for fulfiling consumption needs but for expanding their business. ${ }^{17}$ This was not an isolated case but a prevalent form of business financing in those days. Several tribe members having skill in trading acted essentially like large partnerships, borrowing finance from members of their own tribe or from other friendly tribes, to carry longdistance trade on a large-scale, which theit own tesources would not permit. This is because they could not undertake too many business trips abroad from east to west. The slow means of communication, the difficult terrain and the harsh climate confined them to mainly two caravan trips during the year, one in summer and one in winter. ${ }^{18}$ Accotdingly they collected all the finance they could muster to purchase p. 87

${ }^{15}$ Fakhruddin al-Razi, Tafsir al-Kabir, 2nd. ed. (Tehran: Dar al-Kutub al-Ilmiyyah, d. 606/1209),

${ }^{16}$ Jabir ibn Abdallah, giving a report on the Prophet's Farewell Pilgrimage, said: 'The Prophet, peace and blessings of God be on him, addressed the people and said: All of the riba of Jabillipabis is annulled. The first riba that I annul is our riba, that accruing to Abbas ibn Abd al-Muttalib [the Prophet's uncle]; it is being cancelled completely. (Muslim, Kitab al-Hajj, Bab Hajjat al-Nabi, may peace be on him; also in Musnad Ahmad).

${ }^{17}$ M. Abu Zahrah, Bubutb fi al-Riba, p. 54

${ }^{18} \mathrm{Al}$ Qư'an, 102:2 
the exportable local produce, sell it abroad and bring back what was necessary to satisfy the entire needs of their society for imports during a specific period. Most of the interest-based transactions mentioned in the classical commentaries in relation to the prohibition of riba are loans taken by tribes from each other, each tribe acting like a large partnership company. ${ }^{19}$ Islam abolished the interest-based nature of these relationships and reorganized them on a profit-and-loss sharing basis. The financier got a just share and the entrepreneur did not get crushed under adverse conditions, one of which was the caravan being way-laid on the way.

There is, thus, absolutely no difference of opinion among all schools of Muslim jurisprudence that riba al-nasi'ab stands for interest and, is haram or prohibited. ${ }^{20}$ The nature of the prohibition is strict, absolute and unambiguous. ${ }^{21}$ However, if the return on principal can be either positive or negative, depending on the final outcome of the business, which is not known in advance, it is allowed provided that it is shared in accordance with the principles of justice laid down in the Sbari'ab.

\section{Riba al-Fadl}

While Islam has prohibited interest on loans and allowed trade, it has not allowed everything in trade. This is because it wishes to not merely eliminate the injustice that is intrinsic in the institution of interest on loans as well as all forms of dishonest and unjust exchanges in business transactions, but also close the backdoor to riba because, according to the unanimously accepted legal maxims of Islamic jurisprudence, anything that serves as a means to the unlawful is also unlawful. Since people may be exploited or cheated in several different ways, the Prophet wamed that a Mustim could indulge in riba in seventy (= several) different ways. ${ }^{22}$ This is the reason why the Prophet, peace and blessings of God be on him, said: "Leave what creates doubt in your mind in favour of what does not create doubt" (cited by Ibn Kathir in his commentary on verse 2:275). Caliph Umar was thus inspired to

${ }^{19}$ For an excellent factual presentation on the subject with numerous solid references from primary sources, see Mufti Muhammad Shafi'Mas'alab-e-Sud (Urdu), (1374 AH), pp. 18-23.See also Abu Zahrah, pp. 54-55.

20 cAbd al-Rahman Jaziri, al-, Al-Figh ala al-Madhabib al-Arba'ah, p. 254

${ }^{21}$ Ibid., p.24

${ }^{22}$ From Abu Huraymah: The Prophet, peace be on him, said: "Riba has seventy segments, the least serious being equivalent to a man committing adultery with his own mother" (lbn Majah, $i b i d)$. 
say: "Abstain not only from riba but also from ribab". ${ }^{23}$ Ribab is from rayb which literally means 'doubt' or 'suspicion' and refers to income which has the semblance of riba or which raises doubts in the mind about its rightfulness. It covers all income derived from injustice to, or exploitation of, others. Thus, it may be said in brief that anything that is unjustifiably received as 'extra' by one of the two counterparties to a trade transaction is riba al-fadl, which may be defined in the words of Ibn alArabi as "all excess over what is justified by the counter-value"24.

The Prophet, peace and blessings of God be on him, has indicated, by way of example, at least four different ways of indulging in riba al-fadl. These are not allinclusive but, nevertheless, help us understand the implications of riba al-fadl. The first of these is the exploitation that may take place in trade through the use of unfair means even though trade is by itself allowed. He equated with riba even the cheating of an unsophisticated entrant into the market (ghabn al-mustarsil) and the rigging of prices in an auction with the help of an agent (al-najash). ${ }^{25}$ Analogically one may conclude that the extra money earned through such exploitation and deception falls within the ambit of riba al-fadl.

Another way of being guilty of indulging in riba alfadl is by accepting a reward in return for making a recommendation in favour of a person. ${ }^{26}$ This implies that the performance of an apparently charitable act with the intention of making money surreptitiously is also prohibited. The rationale behind this may be that such a moneymotivated recommendation might give benefit to a person who does not deserve and, thereby, indirectly deprive others who are more deserving.

${ }^{23}$ From Umar ibn al-Khattab: The last verse to be revealed was on riba and the Prophet, peace be on him, was taken without elaborating it to us; so give up not only riba but also ribab [whatever raises doubts in the mind about its tightfulness] (Tbn Majah, Ibid.).).

${ }^{24}$ Ibn Arabi, Abi Bakr Muhammad, Abkam al-Qur'an, (Caito: Al-Matba'ah al-Bahiygah alMisriyyah, d. 543/1148, 1957), p. 242

${ }^{25}$ From Anas ibn Malik: The Prophet, peace be on him, said: "Deceiving a mustaral [an unknowing entrant into the matket] is riba (Suyuti, al-Jami al-Sagbir, under the word ghabr, Kanz al Ummal, Kitab alBuyu, al-Bab al-thani, al-fasl al-thani, on the authority of Sunan al-Bayhaqi) From Abdallah ibn Abi Awfa: The Ptophet, peace be on him, said: "A najish (one who serves as an agent to bid up the price in an auction) is a cursed taker of riba (Cited by Ibn Hajar al-Asqalani in his commentary on al-Bukhari called Fath al-Bari, Kitab al-Buyu, Bab al-najash; also in Suyuti, al-jami al-Sagbir, under the word al-najish and Kanz al-Ummal, op. cit., both on the authority of Tabarani's al-Kabir).

${ }^{26}$ From Abu Umamah: The Prophet, peace be on him, said: "Whoever makes a recommendation for his brother and accepts a gift offered by him has entered riba through one of its large gates" (Bulugh al-Maram, Kitab al-Buyz, Bab al-riba, reported on the authority of Ahmad and Abu Dawud). .* 
A third way of indulging in riba al-fadl is through barter transactions because of the difficulty of measuring the counter-values precisely in such transactions. The Prophet, peace and blessings of God be on him, therefore discouraged barter in a monetized economy and required that the commodity to be exchanged on the basis of barter be sold against cash and the proceedings used to buy the needed commodity. ${ }^{27}$ (Appendix 2, Hadiths C.5, C.6 and C.7)

This leads to the fourth way of indulging in riba alfadl which has received the maximum attention of the fuqaba. A number of authentic baditbs stipulate that, if the same genus of commodities is exchanged against each other, then the same quantity and weight of the commodities (sawna'an bi sawa'in and mithlan bi mithlin or equal for equal and like for like) should be exchanged hand-to-hand (yadan bi yadin). ${ }^{28}$ If the commodities exchanged are different, it does not matter if there is difference in weight and quantity, provided that the exchange takes place hand to hand. One of the implications of this requirement is the elimination of the backdoor to riba (which is referred to in figh as sadd al-dbari'ab). Another implication of these badiths, as understood by the fuqaba, is the prohibition of futures transactions in foreign exchange. This is because, if the rate of exchange is fixed in advance for a futures exchange in currencies, there may be a great deal of injustice if the market rate of exchange changes. The Shari ${ }^{\prime} a b$, therefore, requires that in a futures transaction the exchange must take place on the basis of the rate prevailing on the date of settlement. However, whether hedging, which is one way of managing the risks involved in exchange rate fluctuations, is possible within the constraints of the Shari $a b$ is a question which needs the attention of the fuqaha. ${ }^{29}$

${ }^{27}$ From Abu Said al-Khudri: The Prophet, peace be on him, said: "Do not sell gold for gold except when it is like for like, and do not increase one over the other; do not sell silver for silver except when it is like for like, and do not increase one over the other; and do not sell what is away [from among these] for what is ready". (Bukhari, Kitab al-Buyu, Bab bay al-fiddab bi al-fiddab; also Muslim, Tirmidhi, Nasa'i and Musnad Ahmad). From Abu Said al-Khudri: The Prophet, peace be on him, said: "Gold for gold, silver for silver, wheat for wheat, barley for barley, dates for dates, and salt for salt - like for like, and hand-to-hand. Whoever pays more or takes more has indulged in riba. The taker and the giver are alike [in guilt]". (Muslim, ibid, and Musnad Ahmad).

${ }^{28}$ For futther discussion of these haditbs, see M. Umer Chapra, Towards a just Monetary System, (Leicester, U.K.The Islamic Foundation, 1983), pp. 58-61.

${ }^{29}$ For some further detail on this, see Chapra and Khan, 2000, pp. 80-83. 


\section{Implications of the Two Type s of Riba}

Riba al-nasi'ab and riba al-fadl are, thus, essentially counterparts of the verse "God has allowed trade and prohibited ribd" (2:275). While riba al-nasi'ab relates to loans and is prohibited in the second part of the verse, riba al-fadl relates to trade and is implied in the first part. Because trade is allowed in principle, it does not mean that everything is allowed in trade. Since the injustice inflicted through riba may also be perpetuated through transactions in commodities and currencies, riba al-fadl refers to all such injustices or exploitations. It requires absence of rigging, uncertainty and speculation. It demands a fair knowledge of the prevailing prices and the quality of goods being purchased or sold on the part of both the buyer and the seller. It necessitates the elimination of cheating in prices or quality, and in measures or weights. All business practices which lead to the exploitation of the buyer or the seller must be effectively eliminated. ${ }^{30}$

While riba al-nasi'ab can be defined in a few words, riba al-fadl, interspersing a vast array of business transactions and practices, is not so easy to specify. This is what may have prompted Umar, the Second Caliph, to say: "The Prophet, peace and blessings of God be on him, was taken without elaborating it to us"." The attempt to justify riba al-nasiab or the interest on loans on the basis of this saying of Umar is absolutely fallacious because the reaction of Umar, by way of caution, was to give up not only riba but also ribah.

It is true that the Prophet specified only a few ways of indulging in riba al-fadl and did not indicate all the different ways, as one may have desired. However, this was not necessary and not even feasible. Forms of injustice and exploitation in trade and exchange of currencies have changed over the centuries and it was not possible for anyone to foresee and specify them all 1400 years ago. The Qur'an and the Sumnab are there to provide the principles on the basis of which the Ummab can do so. This is the ongoing challenge to all Muslims - to examine their economic practices

${ }^{30}$ Several types of sales have been prohibited in the Shar' $a b$ with the objective of safeguarding the right of both buyers and sellers. Examples are: najash (rigging and collusion), ghabn al-mustarsil (cheating of an unsophisticated entrant into the market), bayal-hadir li al-badi and talaggi al-rukban (both implying monopsonistic or monopolistic collusion or exploitation to lower or raise prices beyond what is justified by matket conditions), gharar, mubagalah, munabadhah, mulamasah and muzabanah (sales involving uncertainty and speculation or gambling). See, for example, al-Jaziri, Vol.2, pp.273-8 and 28391.

${ }^{31}$ From Umar ibn al-Khattab: The last verse to be revealed was on riba and the Prophet, peace be on him, was taken without elaborating it to us;'so give up not only riba but also ribab [whatever raises doubts in the mind about its rightfulness] 
continually in the light of Islamic teachings and to eliminate all shades of injustice. This is a more difficult task than eliminating riba al-nasi'ab. It requires a total commitment and an overall restructuring of the entire economy within the Islamic framework to ensure justice. This was, and is, the unique contribution of Islam. While riba al-nasi'ab was well-known in the Jabiliyyah, the concept of riba al-fadl was introduced by Islam and reflects the stamp of its own unflinching emphasis on socioeconomic justice.

\section{Concluding Remarks}

The principal reason why the Qur'an has delivered such a harsh verdict against interest is that Islam wishes to establish an economic system where all forms of exploitation are eliminated, and particularly the injustice perpetuated in the form of the financier being assured of a positive return without doing any work or sharing in the risk, while the entrepreneur, in spite of his management and hard work, is not assured of such a positive return. Islam wishes to establish justice between the financier and the entrepreneur.

Under these circumstances it is difficult to see how anyone could justify interest in an Islamic society. The difficulty to understand the prohibition comes from lack of appreciation of the whole complex of Islamic values, and particularly its uncomprising emphasis on socio-economic justice and equitable distribution of income and wealth. Any attempt to treat the prohibition of $r b a$ as an isolated religious injunction and not as an integral part of the Islamic socio-economic order with its overall ethos, goals and values is bound to create confusion. 


\section{REFERENCES}

Abu Zahrah, M. 1970. Bubuth fi al-Riba. Kuwait: Dar al-Buhuth al-Islamiyyah.

Baljon, J.M.S. Jr 1964. The Reforms and Religious Ideas of Sir Sayjid Ahmad Khan. Lahore: Sh, Muhammad Ashraf, $3^{\text {rd }}$ ed.: see also his article on Ahmad Khan in The Encyclopedia of Islam, Vol. 1, pp. 287-8.

Bokare, G.M. 1993. Hindu-Economics: Eternal Economic Order. New Delhi: Janaki Prakashan.

Chapta, M. Umer. 1985. Towards a just Monetary System. Leicester, U.K.:The Islamic Foundation.

Council of Islamic Ideology (Pakistan). 1980). Elimination of Interest from the Economy. Islamabad: Government of Pakistan.

Dawalibi, M. Ma'ruf al-. 1988). Dacwah li Takyif al-Masarif al-Tijariyyah al-Hadirah Ala Ahkam al-Mudarabah wa al-Qirad fi al-Shari'ah al-Islamiyyah:, Al-Dirasat al-Islamiyah. Islamabad. October-December.

Federal Shatiat Court (Pakistan). 1992. Federal Shariab Court Judgment on Interest. Lahore: P.L.D. Publishers.

Ghazali, Abdel Hamid al-. 1990. Al-Arbah wa al-Fawaid al-Masrafiyyab bayn al-Tablil al-Iqtisadi wa al-Hukm al-Shari. Cairo: Markaz al-Iqtisad al-Islami. . 1994. Profit Versus Bank Interest in Economic Analysis and Islamic Law. Jeddah: IRTI/IDB.

Ibn Atabi, Abi Bakr Muhammad (d. 543/1148). 1957. Abkam al-Qur'an. Cairo: AlMatba'ah al-Bahiyyah al-Misriyyah.

Ibn al-Mutahhar, Hasan. 1955. Tadbkirab al-Fuqaba'. Najaf: Matba'ah al-Najaf.

Ibn Kathir, Abu al-Fida Isma il (d. 744/1373) (n.d.), Tafsir al-Qur'an al-Karim (Cairo: Isa al-Babi al-Halabi).

Ibn Manzur, Muhammad ibn Mukarram (d. 711/1311). 1968. Lisan al-Arab. Beirut: Dat Sadir li al-Taba'ah wa al-Nashr.

Ibn Qayyim al-Jawziyyah (d. 751/1350). 1968. A lam al-Muwagqi in. Cairo: Maktabah al-Kulliyyat al-Azhariyyah.

Isfahani, Raghib al- (d.502/1108). 1961. al-Mufradat fi Gbarib al-Qur'an. Caito: Mustafa al-Babi al-Halabi. 
Jassas, Abi Bakr Ahmad ibn Ali al- (d. 370/945). 1957. Abkam al-Qur'an. Cairo: 'Isa al-Babi al-Halabi.

Jaziri, 'Abd al-Rahman, al- (n.d.). Al-Figh ala al-Madhabib al-Arba'ah. Cairo: AlMaktabah al-Tijariyyah al-Kubra, 5th ed.

Johns, C.H.W, John Dow, W.H. Bennett and J. Abelson (n.d.), On the Babylonian, Christian, Hebrew and Jewish views respectively on 'Usury", Engyclopedia of Religion and Ethics. New York: Charles Scribner's Sons). vol. 12.

Katouzian, Homa. 1979. "Riba and Interest in an Islamic Political Economy" in Peoples Mediterranean, March.

Khan, M. Ali. 1992. his review of the book edited Mohsin Khan and Abbas Mitakhor (1987) Theoretical Studies in Islamic Banking and Finance. Houston, Tx: The Institute of Reseatch Islamic Studies), in The Journal of King Abdul Aziz University: Islamic Economics.

Miqdasi, Ibn Qudamah al- (d. 620/1223). 1973 and 1973. Al-Muqni‘. Qatar: Matabi' Qatar al-Wataniyyah.

Noonan, John T. Jr. 1957. The Scholastic Analysis of Usury. Cambridge, MA: Harvard University Press.

Phulwarwi, M. Ja'far Shah. 1967. Commenial Interest ki Fiqhi Haythiyat (Urdu), Lahore: Idrah Thaqafat-e-Islami.

Qaradawi,Yusuf al. 1994. Fava'id al-Bunuk Hiyat al-Riba al-Mubarram. Cairo: Dar al-Sahwah.

Qurtubi, Muhammad ibn Ahmad al-. (d. 463/1070). 1967. Al-Jami' li Abkam alQur'an, popularly known as Tafsir al-Qurtubi. Cairo: Dar al-Kitab al-Arabi li al-Taba'ah wa al-Nashr.

Rahman, Fazlur. 1964. "Riba and Interest", in Islamic Studies, March.

Razi, Fakhruddin al- (d. 606/1209) (n.d), Tafsir al-Kabir (Tehran: Dar al-Kutub alIlmiyyah, 2nd. ed.).

Sanhuri, 'Andl al-. 1953-54. Razzaq al, Masadir al-Haqg fi al-Figh al-Islami. Beirut: Dar Thya' al-Turath al- Arabi.

Saeed, Abdullah. 1995. "The Moral Context of the Prohibition of Riba in Islam Revisited" in The American Journal of Islamic Social Sciences, Winter.

Shafi, Mufti Muhammad. 1955. Mas'ala-e-Sud (Urdu). Karachi: Idarah al-Ma'arif. 
Shah, Syed Yaqub. 1967. Chand Ma'ashi Masa'il awr Islam (Urdu). Lahore: Idarah Thaqafat-e-Islami.

Siddiqi, M. Nejatullah (2004), Riba, Bank Interest and the Rationale of its Probibition (Jeddah: IRTI/IDB).

Udovitch, Abraham. 1970. Partnership and Profit in Medieval Islam. Princeton, NJ: Princeton University Press.

Waliyullah, Shah. 1953. Hujjatullab al-Balighah, Lahore: Qawmi Kutub Khana, tr. Mawlana Abdul Rahim.

Zabidi, Muhammad Murtada al-. 1205/1791 and 1306AH. Taj al-Arus. Cairo: AlMatba'ah al-Khayriyyah. 